\title{
SIKAP WISATAWAN TERHADAP OBYEK WISATA TAMAN KYAI LANGGENG MAGELANG
}

\author{
Ira Astriyani \\ Eka Sudarusman \\ Sekolah Tinggi IImu Manajemen YKPN Yogyakarta \\ ekasud@yahoo.com
}

\begin{abstract}
An attitude descripbes a person's relatively consistent evaluations, feelings, and tendencies toward an object or idea. Attitudes put poeple into a frame of mind of liking or disliking things, of moving toward or away from them. Attitude is the one important of the buying process, especialty for psychological factor. Attitude is the result of learning process. An attitude have three componen, and they componen relations each other. They are cognitive, affective, and behavior. Cognitive are knwolegde and belief an object, affective is a tendeny for the object, and behavior is tendency to make action to the object. The object in this reseach is tourism, that is Taman Kyai Langgeng, Magelang. The objective in this reseach want to know consumer attitude. Tourism object must to analys the atributes of an attitude. They are location, services, facility, and the price an object, based on demoghraphy caracteristic.
\end{abstract}

Keywords: attitude, cognitive, affective, behavior, tourism

\section{PENDAHULUAN}

Sektor pariwisata merupakan sektor yang dapat diandalkan untuk kemajuan perekonomian suatu negara, terutama untuk penerimaan devisa maupun untuk memperluas dan untuk pemertaan kesempatan kerja terutama masyarakat di sekitar obyek wisata. Jawa Tengah yang cukup strategis di tengah-tengah pusat kegiatan ekonomi pulau jawa, memungkinkan untuk memperluas jaringan perdagangan baik antar kota, antar propinsi, antar pulau maupun perdagangan antar negara. Hal ini juga akan mempengaruhi sektor pariwisata yang ada di Jawa Tengah.

Salah satu obyek wisata yang ada di Jawa Tengah adalah obyek wisata Taman Kyai Langgeng, yang berlokasi di Kotamadya Magelang.Taman Kyai Langgeng adalah suatu wahana rekreasi taman yang terlengkap untuk wilayah 
Jawa Tengah. Obyek wisata ini dijadikan tempat rekreasi, sarana pendidikan, dan olahraga bagi keluarga, masyarakat umum, pelajar, dan mahasiswa.

Untuk mengetahui sikap konsumennya maka obyek wisata perlu menganalisis atribut-atributnya yang terdiri dari lokasi, pelayanan, fasilitas, harga tiket. Oleh karena itu untuk mencapai keberhasilannya perlu mengetahui sikap wisatawannya, sehingga setiap obyek wisata harus memiliki beberapa atribut yang harus diperhatikan dalam memperbaiki kualitasnya, seperti :

1. Ketepatan pelayanan yang berkaitan dengan tunggu dan proses.

2. Akurasi pelayanan yang berkaitan dengan kepercayaan pelayanan dan bebas kesalahan-kesalahan dalam pelayanan

3. Kesopanan dan keramahan dalam memberikan pelayanan, terutama bagi mereka yang berinteraksi langsung dengan pelanggan eksternal, seperti operator telepon, layanan keluhan dan pengaduan, petugas keamanan, staff administrasi, kasir, dan lain-lain. Citra pelayanan sangat ditentukan oleh orang-orang yang berada pada garis depan dalam melayani langsung pelanggan eksternal.

4. Tanggung jawab, berkaitan dengan penerimaan pesan dan pengaduan keluhan dari pengunjung.

5. Kenyamanan dalam memperoleh pelayanan berkaitan dengan lokasi ruangan tempat pelayanan, kemudahan menjangkau, tempat parkir kendaraan, kelengkapan informasi, petunjuk dan lain-lain.

6. Kemudahan mendapatkan pelayanan berkaitan dengan banyaknya outlet, banyaknya petugas yang melayani kasir, staff administrasi, dan lain-lain serta fasilitas pendukung lainnya.

7. Atribut pendukung lainnya seperti lingkungan, kebersihan, ruang tunggu dan fasilitas lain.

Obyek wisata tersebut juga harus mengetahui sikap wisatawannya berdasarkan karakteristiknya yaitu jenis kelamin, usia, dan jenis pekerjaan. Diharapkan pihak pengelola dapat terus memacu kekuatan atribut-atribut andalanya, agar secara terus menerus dapat menarik sikap wisatawan. Setiap pengelola yakin bahwa suatu obyek wisata yang memiliki keunggulan atas atribut-atribut di atas, maka dapat dipastikan obyek wisata tersebut mampu menarik sikap wisatawan untuk melakukan kunjungan kembali.

Sikap adalah kecenderungan yang bersifat positip atau negatip yang berhubungan denga obyek psikologi yang berupa simbol, kata-kata, slogan, orang, lembaga dan ide. Dari defenisi tersebut dapat disimpulkan bahwa sikap merupakan suatu kecenderungan yang dipelajari organisasi yang memiliki 
keyakinan yang bersifat tetap. Memiliki sifat yang mengarah pada suatu yang dihadapinya dan diungkapkan dalam bentuk perbuatan, tindakan, ucapan, maupun emosi seseorang. Sikap merupakan hasil dari proses belajar. Peran sikap mencakup juga keadaan mudah terpengaruh atau tendensi untuk berperilaku dalam keadaan tertentu. Terbentuknya sikap dipengaruhi oleh beberapa faktor yaitu keluarga, kelompok kecil, informasi dan pengalaman. Sikap mempunyai pengaruh yang besar terhadap pembelian atau usaha seseorang dalam membeli suatu produk.

Sikap melibatkan tiga komponen yang saling berhubungan, antara lain (Bilson Simamora, 2004): Komponen Cognitive. Komponen cognitive, yaitu pengetahuan dan keyakinan seseorang mengenai sesuatu yang menjadi obyek sikap. Komponen Affective. Komponen affective, yaitu kecendrungan melakukan sesuatu terhadap obyek sikap. Komponen Behavior. Komponen behavior, yaitu melibatkan salah satu prediposisi untuk bertindak terhadap obyek

Berdasarkan latar belakang tersebut tujuan penelitian ini yaitu untuk mengetahui positif atau negatif sikap wisatawan terhadap Obyek Wisata Taman Kyai Langgeng, dan untuk mengetahui ada atau tidaknya perbedaan sikap wisatawan berdasarkan karakteristik jenis kelamin dan jenis pekerjaan. Sebagai responden adalah para pengunjung obyek wisata Taman Kyai Langgeng Magelang, dengan teknik non probability, dengan cara covenience sampling.

\section{KAJIAN TEORI}

\section{Pengertian Sikap}

Pengertian sikap pertama kali digunakan oleh Herbert Spencer (1862) (Bilson Simamora, 2004). Untuk menunjukan sesuatu status mental seseorang. Sikap itu merupakan suatu perasaaan yang tidak desertai oleh kecendrungan untuk berbuat atau bertindak sesuai dengan sikapnya, selanjutnya sikap diarahkan sebagai kesediaan untuk bereaksi terhadap suatu obyek. Adapun obyek dari sikap itu dapat berupa benda, orang, peristiwa, lembaga, nilai-nilai dan sebaginya.

Menurut Zimbardo dan Ebbesen (Kotler, 2000) : Sikap adalah suatu organisasi yang tetap dari motivasi, emosi, persepsi, atau pengamatan atas suatu aspek dari kehidupan individu. Dari definisi tersebut bahwa sikap merupakan suatu kecendrungan yang dipelajari, sikap yang mengarah pada sesuatu yang dihadapinya, dan diungkapkan dalam bentuk perbuatan, tindakan, ucapan maupun emosi seseorang. Sikap tersebut melibatkan tiga komponen yang saling behubungan, antara lain: 
a. Komponen cognitive

Yaitu berupa pengetahuan, kepercayaan atau pikiran yang berdasarkan pada informasi yang behubungan dengan obyek.

b. Komponen affective

Yaitu menunjukan pada dimensi emosional dari sikap yaitu emosi yang berhubungan dengan obyek, obyek disini dirasakan sebagai menyenangkan atau tidak menyenangkan.

c. Komponen behavior

Yaitu melibatkan salah satu prediposisi untuk bertindak terhadap suatu objek, ia akan siap membantu memperhatikan, berbuat sesuatu yang menguntungkan objek itu. Sebaliknya bila ia mencela sikap negaif, maka ia akan mengencam, mencela, menyerang bahkan membinasakan obyek tersebut.

\section{Ciri-Ciri Sikap}

Menurut Walgito (2003) sikap mempunyai beberapa ciri yaitu:

a. Sikap itu tidak dibawa sejak lahir. Ini berarti bahwa manusia pada waktu dilahirkan belum membawa sikap-sikap tertentu terhadap sesuatu objek. Karena sikap tidak dibawa sejak individu dilahirkan, ini berarti bahwa sikap itu terbentuk dalam perkembangan individu yang bersangkutan.

b. Sikap itu selalu berhubungan dengan objek sikap. Oleh karena itu sikap selalu berhubungan dengan objek-objek tertentu, yaitu melalui proses persepsi terhadap objek tersebut.

c. Sikap dapat tertuju pada satu objek saja, tetapi juga dapat tertuju pada sekelompok objek-objek. Bila seseorang mempunyai sikap yang negatif pada seseorang, orang tersebut akan mempunyai kecenderungan untuk menunjukkan sikap yang negatif pula kepada kelompok di mana seseorang tersebut tergabung di dalamnya.

d. Sikap itu dapat berlangsung lama atau sebentar. Secara relatif sikap itu akan lama bertahan pada diri orang yang bersangkutan. Sikap tersebut akan sulit berubah, dan kalaupun dapat berubah akan memakan waktu yang relatif lama. Tetapi sebaliknya bila sikap itu belum begitu mendalam ada dalam diri seseorang, maka sikap tersebut secara relatif tidak bertahan lama, dan sikap tersebut akan mudah berubah.

e. Sikap itu mengandung faktor perasaan dan motivasi. Ini berarti bahwa sikap terhadap ssuatu objek tertentu akan selalu diikuti oleh perasaan tertentu yang dapat bersifat positif (yang menyenangkan) tetapi juga dapat bersifat negatif (yang tidak menyenangkan) terhadap objek tersebut. 


\section{Fungsi-fungsi sikap}

Sikap manusia mempunyai empat fungsi, yaitu : (Walgito, 2003).

a. Fungsi instrumental, atau fungsi penyesuaian, atau fungsi manfaat. Fungsi ini adalah berkaitan dengan sarana tujuan. Disini sikap merupakan sarana untuk mencapai tujuan. Orang memandang sampai sejauh mana objek sikap dapat digunakan sebagai sarana atau sebagai alat dalam rangka mencapai tujuan.

b. Fungsi pertahankan ego. Ini adalah sikap yang diambil seseorang demi untuk mempertahankan ego atau akunya. Sikap ini diambil seseorang pada waktu orang yang bersangkutan terancam keadaan dirinya atau egonya.

c. Fungsi ekspresi nilai. Sikap yang ada pada diri seseorang merupakan jalan bagi individu untuk mengekspresikan nilai yang ada pada dirinya. Dengan mengekspresikan diri seseorang akan mendapatkan kepuasan dapat menunujukkan keadaan dirinya atau egonya.

d. Fungsi pengetahuan. Individu mempunyai dorongan untuk ingin dimengerti, dengan pengalaman-pengalamannya, untuki memperoleh pengetahuan. Elemen-elemen dari pengalamannya yang tidak konsisiten dengan apa yang diketahui oleh individu, akan disusun kembali atau diubah sedemikian rupa hingga menjadi konsisten.

\section{Karakteristik sikap}

Menurut Aritonang (2007) Sikap mempunyai beberapa karakteristik yaitu :

a. Arah sikap yaitu berkaitan dengan setuju atau tidak setuju dari subjek terhadap objek sikap.

b. Intensitas yaitu berkaitan demgan kedalaman atau kekuatan sikap subjek, yakni seberapa setuju atau tidak setuju subjek terhadap objek sikap.

c. Keluasan yaitu berkaitan dengan seberapa spesifik karakteristik objek sikap yang diungkap.

d. Konsisten yaitu berkaitan dengan kesesuaian antara pernyataan sikap yang dikemukakan dengan tanggapannya terhadap objek sikap itu.

\section{Sikap Wisatawan}

Pengetahuan akan sikap wisatawan merupakan suatu hal yang penting bagi Obyek Wisata Taman Kyai Langgeng karena dengan mengetahui sikap wisatawan maka dapat mengetahui dan memahami perilku wisatawan. Oleh karen itu Obyek Wisata Tasman Kyai Langgeng untuk mencapai suatu 
keberhasilan dengan mengetahui dan memahami sikap wisatawan diharapkan bisa sebagai dasar dalam menentukan kebijakan yang tepat agar bisa bertahan dan berkembang serta mampu menghadapi persaingan.

Obyek Wisata Taman Kyai Langgeng dalam mengetahui sikap wisatawan dengan pelayanan Hotline Service, yaitu untuk menerima saran dan kritik dari wisatawan kemudian akan ditampung untuk mencari solusi terhadap kekurangan yang ada serta menjadikan yang lebih baik.

Dalam mengevaluasi sikap wisatawan baik berupa kritik dan saran kepada Obyek Wisata Taman Kyai Langgeng, juga dengan dilakukann wawancara langsung kepada wisatawan yang datang ke Obyek Wisata Taman Kyai Langgeng dimintai penilaian terhadap obyek wisata serta atribut yang ditawarkan sehingga obyek wisata dapat mengetahui kekurangan ataupun kelebihan yang dimilikinya. Maka Obyek Wisata Taman Kyai Langgeng mengadakan In House Sharing setiap Minggu sekali dengan karyawan kemudian mencari jalan yang terbaik bagi perusahan.

\section{Pengukuran sikap}

Menurut Walgito (2003) Didalam pengukuran sikap ada beberapa macam cara, yang secara garis besarnya dapat dibedakan menjadi dua, yaitu secara langsung dan secara tidak langsung. Pengukuran sikap secara langsung pada umumnya digunakan sejumlah sistem yang telah disusun secara hati-hati, seksama, selektif sesuai dengan kriteria tertentu. Pengukuran sikap secara langsung yaitu dimana objek secara langsung diminta pendapat bagaimana sikapnya terhadap suatu masalah atau hal yang diharapkannya. Pengykuran sikap secara langsung yang dipakai adalah pengukuran yang secara langsung yang berstruktur. Pengukuran ini terdiri dari pernyatan-pernyataan yang telah tersususn sedemikian rupa dan langsung dibentuk kepada subjeknya serta bagaimana tangapan mereka terhadap hal ini.

\section{Model Sikap}

a. Teori Fishbein's Attitude

Rainsenberg dan Fishbein's adalah pelopor sikap baru, menurut model sikap Fishbein's bahwa orang membentuk sikap terhadap suatu objek berdasarkan kepercayaan (tanggapan dan ilmu pengetahuan) tentang objek. Kepercayaan diperoleh dengan memproses informasi yang diperoleh dari pengalaman langsung terhadap objek komunikasi tentang kepercayaan yang diperoleh dari sumber-sumber lain. Kepercayaan merupakan dasar pembentukan sikap. Proses informasi membaca pengetahuan atau 
kepercayaan tentang produk dan sebaliknya akan menuntun sikap yang terlibat didalam menilai (mengevaluasi produk). Produk mempunyai banyak sifat (ukuran, bentuk, cirri-ciri, dan lain-lain). Seseorang akan memproses informasi dan membentuk kepercayaan tentang sifat-sifat positif maupun negatif, berdasarkan kepercayaan yang dimilikinya. Didalam menentukan sikap seseorang secara keseluruhan terhadap obyek, menentukan kepercayaan yang sangat relevan, ini disebut salient beliefs (kepercayaan yang sangat menonjol). Model Fishbein's disusun sehingga sikap seseorang secara keseluruhan terhadap beberapa obyek yang diperoleh dan kepercayaan dan evaluasi (penilaian) tentang berbagai sifat obyek, dan dalam pengukuran digunakan skala bipolar (skala yang memiliki dua kutub). Kedua pelopor tersebut mempunyai persamaan dalam menganalisis terhadap sikap.

Fishbein's dirumuskan sebagai berikut:

$$
A o=\sum_{i=0}^{n} b i . e i
$$

Dimana:

Ao : Sikap (attitude) seseorang yang secara keseluruhan terhadap obyek.

bi : Kepercayaan (believe) seseorang terhadap kekuatan kepercayaan terhadap obyek.

ei : penilaian (evaluasi) yang ada pada seseorang atribut (i) yang ada pada suatu obyek.

$\mathrm{n}$ : Jumlah atribut.

Dengan demikian model tersebut mengemukakan bahwa sikap terhadap objek tertentu didasarkan pada perangkat kepercayaan yang diringkas mengenai atribut obek yang bersangkutan, yang diberi bobot oleh evaluasi terhadap atribut ini. Sehingga semakin besar perangkat kepercayaan konsumen terhadap suatu produk tertentu maka sikap konsumen terhadap produk tersebut semakin besar.

\section{b. Chy Square Test}

Analisis ini digunakan untuk menghitung apakah ada perbedaan sikap wisatawan berdasarkan karateristik jenis kelamin, usia, jenis pekerjaan, dan tingkat pendapatan. 
Rumus :

$$
\mathrm{x}^{2}=\sum_{i=1}^{\mathrm{k}} \frac{(o i j-e i j)}{\mathrm{Eij}}
$$

Keterangan :

$\mathrm{x}^{2}$ : Hasil uji Chy Square

oij : Merupakan frekuensi hasil observasi.

eij : Merupakann frekuensi hasil yang diharapkan

Dan untuk menghitung eij dapat dihitung dengan rumus :

$$
\text { Eij. } i j=\frac{(n i)(n j)}{(n)}+\frac{(\text { jumlah sebaris }) x(\text { jumlah sekolom })}{(\text { jumlah data })}
$$

\section{PEMBAHASAN}

\section{Analisis Fishbein's}

Alat yang digunakan untuk mengukur sikap wisatawan dalam penelitian ini dengan menggunakan analisis Fishbein's. Analisis ini digunakan untuk mengetahui sikap wisatawan terhadap obyek wisata Taman Kyai Langgeng di Magelang berdasarkan tingkat keyakinan dan penilaian terhadap atribut-atribut yang dimiliki oleh obyek wisata Taman Kyai Langgeng di Magelang yaitu lokasi, pelayanan, fasilitas, dan harga.

a. Analisis terhadap Komponen Keyakinan (bi)

Analisis ini digunakan untuk menggambarkan keyakinan wisatawan terhadap obyek wisata Taman Kyai Langgeng di Magelang, di antaranya adalah:

1. Nilai skor setiap atribut adalah skor keyakinan setiap wisatawan secara individu

2. Bobot penilaian yang diberikan adalah sebagai berikut:

$\begin{array}{lll}\text { SS } & \text { : Sangat Setuju Bobot } & 4 \\ \text { S } & \text { : Setuju Bobot } & 3 \\ \text { N } & : \text { Netral Bobot } & 2 \\ \text { TS } & \text { : Tidak Setuju Bobot } & 1 \\ \text { STS } & \text { : Sangat Tidak Setuju Bobot } & 0\end{array}$

Secara ringkas dapat dilihat pada tabel berikut: 
Tabel 1.

Skor Keyakinan (bi)

\begin{tabular}{crcc}
\hline No & \multicolumn{1}{c}{ Atribut } & Jumlah Skor & Rata-rata Skor \\
\hline 1. & Lokasi & 253,67 & 2,53 \\
2. & Pelayanan & 238,67 & 2,38 \\
3. & Fasilitas & 231,00 & 2,31 \\
4. & Harga & 297,69 & 2,97 \\
\hline
\end{tabular}

Sumber: data diolah

Dari penghitungan nilai skor rata-rata keyakinan (bi) tiap-tiap atribut diatas dapat diketahui bahwa keyakinan wisatawan terhadap atribut obyek wisata Taman Kyai Langgeng di Magelang tertinggi adalah atribut harga dengan rata-rata skor nilai 2,97, kedua adalah atribut lokasi dengan rata-rata skor nilai 2,53, ketiga adalah atribut pelayanan dengan rata-rata skor nilai 2,38 yang terakhir adalah atribut fasilitas dengan rata-rata skor nilai 2,31.

b. Analisis terhadap Komponen Penilaian (ei)

Analisis ini digunakan untuk mengetahui penilaian wisatawan terhadap obyek wisata Taman Kyai Langgeng di Magelang, diantaranya adalah:

1. Nilai skor dari tiap-tiap atribut adalah skor penilaian setiap wisatawan secara individu

2. Bobot penilaian yang diberikan adalah sebagai berikut:

$\begin{array}{lll}\text { SB } & \text { : Sangat Baik Bobot } & 3 \\ \text { B } & \text { : Baik Bobot } & 2 \\ \text { N } & \text { : Netral Bobot } & 1 \\ \text { TB } & \text { : Tidak Baik Bobot } & 0 \\ \text { STB } & \text { : Sangat Tidak Baik Bobot } & -1\end{array}$

Secara ringkas dapat dilihat pada tabel berikut:

Tabel 2.

Skor evaluasi (ei)

\begin{tabular}{crcc}
\hline No & Atribut & Jumlah Skor & Rata-rata Skor \\
\hline 1. & Lokasi & 124,67 & 1,24 \\
2. & Pelayanan & 201,00 & 2,01 \\
3. & Fasilitas & 178,67 & 1,78 \\
4. & Harga & 143,67 & 1,43 \\
\hline
\end{tabular}

Sumber: data diolah 
Dari penghitungan nilai skor rata-rata penilaian (ei) tiap-tiap atribut diatas dapat diketahui bahwa penilaian wisatawan terhadap atribut obyek wisata Taman Kyai Langgeng di Magelang adalah positif, dengan urutan nilai yang tertinggi adalah atribut pelayanan dengan rata-rata skor nilai 2,01 untuk urutan kedua adalah atribut fasilitas dengan rata-rata skor nilai 1,78, selanjutnya urutan ketiga adalah atribut harga dengan rata-rata skor nilai 1,43 dan urutan yang terakhir adalah atribut lokasi dengan rata-rata skor nilai 1,24.

c. Analisis Skor Sikap Wisatawan

Analisis ini digunakan untuk mengetahui sikap wisatawan terhadap obyek wisata Taman Kyai Langgeng di Magelang apakah positif atau negatif, yang akan dianalisis dengan rumus Fishbein's sebagai berikut:

$$
A o=\sum_{i=0}^{n} b i . e i
$$

Hasil penilaian sikap wisatawan terhadap obyek wisata Taman Kyai Langgeng di Magelang secara ringkas dapat dilihat pada tabel berikut:

Tabel 3.

Analisis Skor Sikap Wisatawan (A0)

\begin{tabular}{clccc}
\hline No & Atribut & bi & ei & Sikap (A0) \\
\hline 1. & Lokasi & 2,53 & 1,24 & 3,13 \\
2. & Pelayanan & 2,38 & 2,01 & 4,78 \\
3. & Fasilitas & 2,31 & 1,78 & 4,11 \\
4. & Harga & 2,97 & 1,43 & 2,42 \\
\hline Rata-rata & \multicolumn{3}{c}{4,06} \\
\hline
\end{tabular}

Sumber: data diolah

Berdasarkan hasil perkalian antara skor keyakinan (bi) dengan skor penilaian (ei) dapat diketahui bahwa rata-rata skor pelayanan mempunyai peringkat tertinggi dengan rata-rata skor 4,78, urutan kedua adalah harga yang memiliki nilai rata-rata skor 4,24 , untuk urutan ketiga adalah fasilitas dnegan nilai rata-rata skor 4,11 , dan untuk urutan yang terakhir adalah lokasi dengan nilai rata-rata skor 3,13.

Hasil diatas menunjukkan bahwa sikap wisatawan terhadap atribut-atribut obyek wisata Taman Kyai Langgeng di Magelang adalah positif. Adapun 
hasil sikap wisatawan terhadap atribut-atribut secara keseluruhan diperoleh nilai rata-rata sebesar 4,06, sehingga dapat dinyatakan sikap wisatawan terhadap obyek wisata Taman Kyai Langgeng di Magelang adalah positif.

Dengan demikian hipotesis penelitian yang menyatakan bahwa wisatawan mempunyai sikap yang positif terhadap atribut-atribut obyek wisata Taman Kyai Langgeng di Magelang, terbukti.

\section{Analisis Chi Square Test}

Analisis ini digunakan untuk mengetahui ada tidaknya perbedaan sikap wisatawan terhadap obyek wisata Taman Kyai Langgeng berdasarkan karakteristik responden yaitu jenis kelamin, usia, tingkat pendapatan, jenis pekerjaan.

a. Analisis Perbedaan Sikap Wisatawan Berdasarkan Karakteristik Jenis Kelamin

Berdasarkan hasil perhitungan sikap konsumen secara individual berdasarkan karakteristik jenis kelamin diperoleh hasil sebagai berikut:

Tabel 4.

Frekuensi Pengamatan Sikap Wisatawan (oij)

Berdasarkan Karakteristik Jenis Kelamin

\begin{tabular}{lccccc}
\hline Jenis Kelamin & Lokasi & Pelayanan & Fasilitas & Harga & Jumlah \\
\hline Pria & 2,9633 & 4,6573 & 3,9827 & 4,1057 & 15,7089 \\
Wanita & 3,1464 & 4,8632 & 4,1600 & 4,3239 & 16,4935 \\
\hline Jumlah & 6,1097 & 9,5205 & 8,1427 & 8,4296 & 32,2024 \\
\hline
\end{tabular}

Sumber: data diolah

Untuk membuktikan signifikan atau tidak hasil di atas, maka dilakukan uji hipotesis sebagai berikut:

a) Menentukan hipotesis nol $(\mathrm{Ho})$ dan hipotesis alternative $(\mathrm{Ha})$

Ho: $x^{2}=0$, berarti tidak ada perbedaan sikap wisatawan terhadap atribut-atribut obyek wisata Taman Kyai Langgeng berdasarkan karakteristik jenis kelamin.

$\mathrm{Ha}: \mathrm{x}^{2} \neq 0$, berarti ada perbedaan sikap wisatawan terhadap atribut- 
atribut obyek wisata Taman Kyai Langgeng berdasarkan karakteristik jenis kelamin.

b) Menentukan tabel berdasarkan level of significance $\alpha=5 \%(0,05)$ dan derajat kebebasan (df) yaitu:

$$
\begin{aligned}
\mathrm{df} & =(\text { baris }-1)(\text { kolom }-1) \\
& =(2-1)(4-1) \\
& =3
\end{aligned}
$$

Dengan derajat kebebasan 3 serta level of significance $\alpha=5 \%$ maka diperoleh nilai tabel sebesar $(7,815)$

c) Menentukan hitung

Hasil perhitungan di atas diperoleh besarnya nilai hitung $=0,000355$.

d) Kriteria pengujian

Ho diterima atau Ha ditolak apabila hitung $\leq$ tabel

Ho ditolak atau Ha diterima apabila hitung $>$ tabel

e) Hasil pengujian

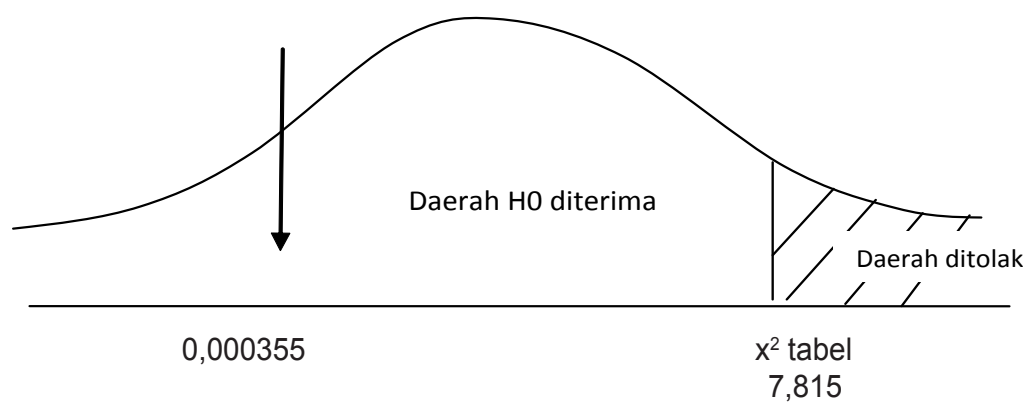

Gambar 1.

Daerah Penolakan dan Penerimaan Ho

Uji Chi Square Sikap Konsumen

Berdasarkan Jenis Kelamin

Berdasarkan kriteria pengujian di atas diperoleh hasil hitung $(0,000355)<$ tabel $(7,815)$ atau Ho diterima, artinya tidak ada perbedaan sikap konsumen berdasarkan jenis kelamin.

Hasil ini menunjukkan bahwa sikap wisatawan terhadap obyek wisata Taman Kyai Langgeng di Magelang tidak dipengaruhi oleh perbedaan karakteristik 
berdasarkan jenis kelamin. Hal ini karena pada prinsipnya wisatawan pria maupun wanita bersikap sama terhadap lokasi, pelayanan, fasilitas dan harga terhadap obyek wisata Taman Kyai Langgeng di Magelang.

b. Analisis Perbedaan Sikap Wisatawan Berdasarkan Karakteristik Jenis Pekerjaan

Berdasarkan hasil perhitungan sikap konsumen secara individual berdasarkan karakteristik jenis pekerjaan diperoleh hasil sebagai berikut:

Tabel 5.

Frekuensi Pengamatan Sikap Wisatawan (oij)

Berdasarkan Karakteristik Jenis Pekerjaan

\begin{tabular}{lrrrrc}
\hline Jenis Pekerjaan & \multicolumn{1}{c}{ Lokasi } & Pelayanan & Fasilitas & Harga & \multicolumn{1}{l}{ Jumlah } \\
\hline Pelajar & 2,3777 & 4,2950 & 3,8896 & 3,7235 & $\mathbf{1 4 , 2 8 5 8}$ \\
Mahasiswa & 3,2041 & 4,2126 & 4,0292 & 4,5476 & $\mathbf{1 5 , 9 9 3 5}$ \\
Wiraswasta & 3,3867 & 5,2830 & 4,3865 & 4,5422 & $\mathbf{1 7 , 5 9 8 4}$ \\
Pegawai Negeri & 3,5301 & 5,0335 & 4,3640 & 4,6632 & $\mathbf{1 7 , 5 9 0 8}$ \\
Pegawai Swasta & 2,9613 & 4,8092 & 3,8895 & 3,9719 & $\mathbf{1 5 , 6 3 1 9}$ \\
\hline Jumlah & $\mathbf{1 5 , 4 5 9 9}$ & 23,6333 & 20,5588 & 21,4484 & 81,1004 \\
\hline
\end{tabular}

Sumber: data diolah

\section{Pengujian Hipotesis}

Untuk membuktikan signifikan atau tidak hasil di atas, maka dilakukan uji hipotesis sebagai berikut:

a) Menentukan hipotesis nol $(\mathrm{Ho})$ dan hipotesis alternative $(\mathrm{Ha})$

Ho: $x^{2}=0$, berarti tidak ada perbedaan sikap wisatawan terhadap atribut-atribut obyek wisata Taman Kyai Langgeng berdasarkan karakteristik jenis pekerjaan.

Ha: $x^{2} \neq 0$, berarti ada perbedaan sikap wisatawan terhadap atributatribut obyek wisata Taman Kyai Langgeng berdasarkan karakteristik jenis pekerjaan.

b) Menentukan tabel berdasarkan level of significance $\alpha=5 \%(0,05)$ dan derajat kebebasan (df) yaitu:

$$
\begin{aligned}
\mathrm{df} & =(\text { baris }-1)(\text { kolom }-1) \\
& =(5-1)(4-1) \\
& =12
\end{aligned}
$$


Dengan derajat kebebasan 12 serta level of significance $\alpha=5 \%$ maka diperoleh nilai tabel sebesar $(21,026)$.

c) Menentukan hitung

Hasil perhitungan di atas diperoleh besarnya nilai hitung $=0,1867$.

d) Kriteria pengujian

Ho diterima atau Ha ditolak apabila itung $\leq$ tabel

Ho ditolak atau Ha diterima apabila hitung > tabel

e) Hasil pengujian

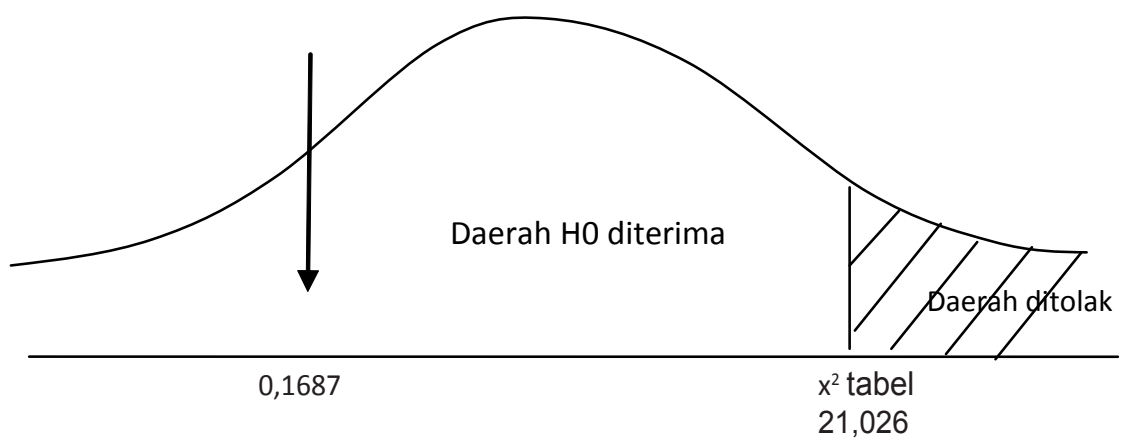

Gambar 2.

Daerah Penolakan dan Penerimaan Ho

Uji Chi Square Sikap Konsumen Berdasarkan

Jenis Pekerjaan

Berdasarkan kriteria pengujian di atas diperoleh hasil hitung $(0,1867) \leq$ tabel $(21,026)$ atau Ho diterima, artinya tidak ada perbedaan sikap konsumen berdasarkan jenis pekerjaan.

Hasil ini menunjukkan bahwa sikap wisatawan terhadap obyek wisata Taman Kyai Langgeng di Magelang tidak dipengaruhi oleh perbedaan karakteristik berdasarkan jenis pekerjaan. Hal ini karena pada prinsipnya wisatawan yang mempunyai pekerjaan pelajar, mahasiswa, wiraswasta, pegawai negeri, pegawai swasta bersikap sama terhadap lokasi, pelayanan, fasilitas dan harga terhadap obyek wisata Taman Kyai Langgeng di Magelang. 


\section{SIMPULAN}

Hasil penghitungan rata-rata skor sikap responden dengan model Fishbein's menunjukkan bahwa atribut-atribut Obyek Wisata Taman Kyai Langgeng yang tertinggi adalah atribut harga dengan rata-rata skor nilai 2,97 dan kedua adalah atribut lokasi dengan rata-rata skor nilai 2,53 dan ketiga adalah atribut pelayanan dengan rata-rata skor nilai 2,38 dan yang terakhir adalah atribut fasilitas dengan rata-rata skor nilai 2,31. Hasil skor sikap responden terhadap Obyek Wisata Taman Kyai Langgeng di Magelang menunjukkan sikap yang positif. Dengan demikian hipotesis pertama yang menyatakan bahwa wisatawan mempunyai sikap positif terhadap Obyek Wisata Taman Kyai Langgeng di Magelang telah terbukti.

Berdasarkan karakteristik jenis kelamin menunjukkan bahwa tidak ada perbedaan sikap wisatawan terhadap Obyek Wisata Taman Kyai Langgeng di Magelang.. Berdasarkan karakteristik jenis pekerjaan menunjukkan bahwa tidak ada perbedaan sikap wisatawan terhadap Obyek Wisata Taman Kyai Langgeng di Magelang berdasarkan jenis pekerjaan.

Hasil temuan menunjukkan skor terendah pada atribut fasilitas, sehingga obyek wisata perlu memperhatikan fasilitas di obyek wisata, tanpa mengabaikan atribut yang lain yang sudah memiliki skor yang lebih tinggi. Skor yang tinggi untuk tetap dipertahankan bahkan untuk ditingkatkan.

\section{DAFTAR PUSTAKA}

Agustina Dwi Astuti, (2005), Sikap Wisatawan Terhadap Obyek Wisata Candi Borobudur Magelang, Skripsi : Tidak dipublikasikan.

Aritonang R,Lerbin R, (2007), Riset Pemasaran Teori dan Praktek, Edisi Pertama, Ghalia Indonesia, Jakarta.

Bhuana Agung, (2006), Cara Praktis SPSS 15.0, Yogyakarta, Balai Pustaka

Bilson Simamora, (2004), Panduan Riset Perilaku Konsumen, Jakarta: PT. Gramedia Pustaka Utama.

Husein Umar (2003), Metode Penelitian Aplikasi Dalam Pemasaran, Gramedia, Jakarta.

James. F. Engel, Roger. D. Blackwell, Paul Winiard (1994), Consumer Behaviors, Second Edition Illinois, Hins Dale. 
Kotler, Philip, (2007), Manajemen Pemasaran, Jilid 1, Edisi bahasa indonesia, PT.Macanan Jaya Cemerlang, Jakarta.

Kotler, Philip, (2000), Manajemen Pemasaran, Jilid 1, Edisi Milenium, PT.Prenhalindo, Jakarta.

Swasta DH, Basu dan T.Hani Handoko, (2000), Manajemen Pemasaran Analisa Perilaku Konsumen, Edisi Pertama, BPFE, Yogyakarta.

Soeratno dan Lincolin Arsyad (1999), Metodologi Penelitian Untuk Ekonomi dan Bisnis, UPP AMP YKPN, Yogyakarta

Subagyo (1994), Statistik Induktif, BPFE, Yogyakarta.

Walgito, Bimo, (2003), Psikologi Sosial (suatu pengantar), Edisi ReviSI Penerbit Andi, Yogyakarta. 